Tourism Research Journal

E-ISSN: 2598-9839

2018, Vol. 2 No. 1

\title{
The Effect of Destination Management and Community Participation to The Visitors Consumption at Tebing Breksi Sleman Yogyakarta
}

\author{
Rakhmat Ashartono ${ }^{1}$, Myrza Rahmanita ${ }^{2}$, Diena Mutiara Lemy ${ }^{3}$ \\ ${ }^{1}$ Sekolah Tinggi Pariwisata Ambarukmo \\ 2,Sekolah Tinggi Pariwisata Trisakti \\ 3,Sekolah Tinggi Pariwisata Pelita Harapan \\ Ashartono_rakhmat@yahoo.com
}

\begin{abstract}
The development of a new tourist destination indeed needs more attention to increase the number of tourist arrivals coming in an area. Breksi Cliff is one of the new destinations in Sleman district which is in the development period, with the development of Breksi cliff is expected to increase the level of welfare of the surrounding community through the development of the destination and community participation itself. This research is a research with descriptive method of analysis with quantitative approach to know accurate information about matters related to Tourism Destination Management and Public Participation to Welfare Society through Visitor Consumption. for the data analysis techniques alone will use Structural Equation Modeling. From the results of the study found that the level of community welfare Taman Tebing Breksi can increase with the management of destinations and community participation itself through the consumption of visitors
\end{abstract}

Keywords: Tourist destination development, public participation, structural equation modeling 
The Effect Of Destination Management And Participation Of The Community To The Consumption Of Visitor For The Welfare Of The Tebing Breksi

Sleman Yogyakarta

\section{A. Introduction}

The beginning of Tebing Breksi development is done by Karang Taruna Dusun Gunungsari \& Dusun Nglengkon under Pokdarwis Sambisari Village. Mas April as one of the daily coordinator of the management of Tebing Breksi explained that the community around Tebing Breksi lost their livelihoods as miners since 2005 because the mining is abandoned, this is due to illegal mining. Still based on information from the next April in mid2015 with the help of capital provided by Sleman Local Government then initiated the development of the Tebing Breksi destination conducted by Karang Taruna two sub-villages under the supervision of Pokdarwis Sambirejo Village. Now the Sleman Local Government is only attracting parking fees, while the incoming levy is voluntarily collected for part of the wage for the people who are on duty each day so that the Tebing Breksi are really purely managed by the participation of the community itself.

In its development Tebing Breksi have been able to bring tourists in considerable numbers and become one of the favorite tourist destinations in Yogyakarta, tourist visits can reach an average of 600 wisnus per day during the weekdays while reaching 5,000 people during the weekend. (Source: Guest Book Manager of Tebing Breksi). While Mrs. Mimin as one of the sellers in Tebing Breksi provide information that the development of Tebing Breksi is enough to contribute to the income of the surrounding community, especially those who open food stalls, turnover of people who now sell in the area Tebing Breksi can reach 700,000 - 800,000 per day.

The management of a tourist destination cannot be separated from the participation of the community, especially the community around the tourist destination area, as well as this Breksi Cliff Park where local communities or local communities directly involved in the management of this tourist destination. Community participation here can be seen from the direct involvement of pokdarwis in Sambirejo Village in the management of Taman Tebing Breksi, where they manage this destination in full with the capital provided by the Local Government through the Tourism Department. Evidently, with this community participation, Taman Bruce Breksi, previously only a stone leftover mining could be a tremendous tourist attraction.

With the development of Breksi Cliff Park is making the number of tourists who visit this destination which of course they are not just doing tourism activities, they will indirectly also use the existing facilities in Taman Tebing Breksi as an example is when they feel tired after climbing to the top of the cliff then they will find a place to rest which is of course also available there, while resting this they will also order food or beverage. Here the participation of local communities in terms of service provision of food and beverages is necessary in relation to the consumption or tourist shopping. So that the management of destinations undertaken by local pokdarwis will certainly affect the level of consumption or tourist spending in this Breksi Cliff Park.

Tourism Research Journal, Volume 2 (1), 2018 
The Effect Of Destination Management And Participation Of The Community To The Consumption Of Visitor For The Welfare Of The Tebing Breksi

Sleman Yogyakarta

\section{B. Literature Review}

\section{Destination Management}

As has been described in the background that a tourist destination will be developed with good management and community participation, the following will be given a study that explains how the management of destinations that will later become variable X1.

Tourist Destinations or Tourism Areas are understood to be a meeting point between supply and demand that geographically confronts the merging challenge to become a consistent tourism product (Dredge, 1999; Sainaghi, 2006) .As for the management of this destination it is suggested to be managed in a network in a journal stated that:

Recent attention to destination governance has been the product of a growing interest in the potential benefits and drawbacks of managing tourist destinations in the form of networks. Several authors have suggested that the development of tourist destinations (Dredge, 2006; Moscardo, 2011; Nordin \& Svensson, 2007; Raich, 2006; Ritchie \& Crouch , 2003).

Related to the management of this tourist destination is part of the existence of tourism management where According to Pitana and Diarta (2009), tourism management should pay attention to the following principles:

1. Tourism development and development should be based on local wisdom and special local sense that reflects the uniqueness of cultural heritage and the uniqueness of the environment.

2. Preservation, protection and enhancement of the quality of the resources it becomes base of tourism area development.

3. The development of additional attractions that are rooted in the treasures local culture.

4. Service to tourists based on the uniqueness of local culture and environment.

5. Provide support and legitimacy to development and tourism development if proven to provide positive benefits, but instead control and / or stop the tourism activity if it exceeds the carrying capacity of the natural environment or social acceptability, although on the other hand can increase the income of the community.

As for the method of tourism management includes several activities as follows:

1. Consultation with all stakeholders.

2. Identify the issue.

3. Policy formulation.

4. Establishment and funding of agents with special tasks.

5. Provision of facilities and operations.

6. Provision of fiscal policies, regulations and a conducive social environment.

7. Resolving conflicts of interest in the community (Richardson and Fluker 2004).

Tourism Research Journal, Volume 2 (1), 2018 
The Effect Of Destination Management And Participation Of The Community To The Consumption Of Visitor For The Welfare Of The Tebing Breksi

Sleman Yogyakarta

8. Relation to the management of destination, will be measured by some indicators taken from the component of the destination itself, namely:

9. Attractions (attractions), which broadly offer travelers the option to travel and also provide motivations for potential tourists in which include nature tourism, cultural tourism, artificial tourism, social tourism (Cooper, 2005, Middleton, 2001)

10. Accessibility, which generally makes it easy for tourists to reach a tourist destination, so that potential travelers have no trouble in traveling to these tourist destinations as well as the availability of local transportation that can be utilized to serve tourists. (Cooper, 2005, Middleton, 2001).

11. Amenitas (Amenities), here can be said by how the future tourists can stay or stay in a destination so that he can get involved in the activities of tourist attractions in the destination. (Middleton 2001). For Amenitas this will be measured by several things according to (Chi-Ok Oh, Jason Draper, Anthony W. Dixon, 2010) namely:

a. Access Point.

b. Land or Parking User Fee

c. Noise Level.

d. Development, in this case the development of restaurants and hotels.

e. Rules.

12. Tourism Organization (Anchillary). Organizations that are associated with tourism that will be able to market the existing tourist destinations in the place and how to manage the destination so that it can be known to many people. (Cooper, 2005). For this Anchilary will be measured from the following points:

a. Responsible organization, where on the destination there is an official Organization responsible for coordinating the management of tourism.

b. Government and private involvement, where private and government parties are involved in tourism organization and coordination in Destinations.

c. Size and Scale of the Organization, where the existing Tourism Organization meets the size and scale of the destination.

d. Individual responsibility, where tourism is given responsibility for tourism development.

e. Organization Funds, whereby this Tourism Organization has adequate funding (ISTA 2017 Assessment Matrix)

\section{Community Participation}

Participation is defined as an effort of community participation in an activity both in the form of statements and activities. Furthermore, it can be said that participation is the participation of the community in development programs. The idea of community participation is also expressed by Slamet (2003), the

Tourism Research Journal, Volume 2 (1), 2018 
The Effect Of Destination Management And Participation Of The Community To The Consumption Of Visitor For The Welfare Of The Tebing Breksi Sleman Yogyakarta

meaning of community participation in development can be interpreted as the participation of the community in development, participate in development activities from the planning, implementation / implementation, monitoring and evaluation stages, enjoy the results of development. The emphasis here is that participation in development not only contributes to contributing inputs to the development process, but includes sharing and enjoying the results of development. So it can be said that the success of national development is determined by the level of community participation, both in contributing inputs and in enjoying the results. The importance of participation in development means that everything related to economic policy making, such as attracting outside investors, Bryson 1995). Then Adiyoso (2009) asserted that community participation is the most important component in an effort to grow independence and empowerment process.

Furthermore Sztompka (2007, p.65) states that humans exist every moment from the future to the future. Society is not a physical entity, but a set of interrelated processes are double-deckered. Its presence precisely through the phase between what has happened and what will happen. In today's society there are influences, traces, and past copies and seeds and potential for the future. The implied nature of society implies that the preceding phase is causal with the present phase and the present phase is the causative requirement that determines the next phase. This community participation will be made as a variable X2 .

For this community participation will be measured from two indicators (ISTA 2017 Assessment Matrix), namely:

a. Engagement of stakeholders, where systems involving stakeholders from government, industry and community in destination management and decisionmaking planning.

b. Annual meetings of the community, where meetings are held annually with the community to discuss destination management issues.

\section{Visitors Consumption}

There are several ways that can be made to make estimations of total travel expenditures (Goldman, Nakazawa and Taylor, 2008):

a. Analyze the diaries records.

b. Conducting interviews to some sample travelers when they leave the destination.

c. Send home mail to visitors at home.

d. Conducting survey on tourism business.

The results of the identification and analysis of tourist expenditures result in elements of tourist expenditures that can be grouped into 13 main groups of accommodation, food and beverages, souvenirs, shopping, local transport, local tour packages, domestic flights, cruises, entertainment, health and beauty, tour guides, and others. In Indonesia the largest expenditure is accommodation ie $21.77 \%$ of total expenditure (Saptutyningsih, 2003).

Tourism Research Journal, Volume 2 (1), 2018 
The Effect Of Destination Management And Participation Of The Community To The Consumption Of Visitor For The Welfare Of The Tebing Breksi Sleman Yogyakarta

Consumption of visitors or tourists can be measured based on the level of tourist spending. Nicolau \& Mas (2005) mentioned some of these indicators are:

a. Distance between the area of origin of tourists and destinations.

b. Type of accommodation used.

c. Tourist income.

d. Number of family members.

e. Marital status and

f. Length Of Stay (length of stay).

With the consumption of visitors or tourists as this Intermediary or intermediary variable then the welfare of Breksi cliff community with some indicators can be directly influenced pengukurnya, so when this Breksi Cliff can be managed well by the surrounding community it will be able to bring tourists to visit. Then with their visit to the Breksi Cliff this of course will bring additional revenue for the surrounding community through the consumption of tourists, although there is a problem where tourists can not stay around this Breksi Cliff because the unavailability of lodging that has been operating but people can still get income from food and beverages sold in the area of Taman Tritis Breksi. The following will be reviewed on how the welfare of the community.

\section{Welfare}

As has been explained the welfare of the community is an objective of this research, so the management of Breksi Climbing Park and community participation of Breksi cliffs will be influential whether it is positive or negative to the welfare of the cliff Breksi community through the intermediate variable is the consumption of visitors or tourists.

Badrudin (2012) describes the welfare of society is a condition that shows about the state of community life that can be seen from the standard of community life. Todaro and Stephen C. Smith (2006) pointed out that community welfare shows the measure of community development outcomes in achieving a better life that includes: first, capacity building and equitable distribution of basic needs such as food, housing, health and protection. Second, Increased life level, income level, better education and increased attention to culture and human values. And thirdly, expand the scale of the economy and the availability of social choice of individuals and nations. The welfare of the community is a condition of the fulfillment of basic needs as reflected by adequate housing, adequate food and clothing needs, cheap and quality education and health costs or conditions in which individuals are able to maximize their utility at a certain level of budget and conditions in which physical and spiritual needs are met.

Then in Law No. 11 of 2009, on the Welfare of the People states that the welfare of society is the condition of the fulfillment of material, spiritual, and social needs of citizens in order to live properly and able to develop themselves, so as to carry out its social functions.

Tourism Research Journal, Volume 2 (1), 2018 
The Effect Of Destination Management And Participation Of The Community To The Consumption Of Visitor For The Welfare Of The Tebing Breksi

Sleman Yogyakarta

From some of the above understanding can already be understood about the meaning of the welfare of society itself. Furthermore, to measure the variable welfare of this community the authors use data from the Central Bureau of Statistics (2005), where indicators used to determine the level of welfare there are eight namely:
a. Income
b. Consumption or family expenditure.
c. State of residence.
d. d.Accommodation facilities.
e. Health of family members.
f. Ease of getting health services.
g. Ease of entry into education level.
h. Easy access to transportation facilities.

\section{Research Methodology}

This research begins with an observation first, then found some interesting things to be researched. The first is the management of destinations that can affect the welfare of the Tebing Breksi community, the second is the participation of the community with the consumption of visitors as an intermediate variable can also affect the level of welfare of the Tebing Breksi Community.

In a study of course requires the population and also the sample used to measure than the variables that exist. According Suharsimi Arikunto (2006: 131) population is the entire subject of the research, in other words the population is a region consisting of objects or subjects that have the number and characteristics of certain studied then drawn conclusions. Then Sample is defined as part of the number of characteristics possessed by the population (Sugiyono, 2008: 118).

\section{Population}

The population used as the sampling in this study is the Visitors of Taman Tebing Breksi for 1 week where the highest visit occurred on Saturday and Sunday with a total of 5,000 people, on weekdays between Monday and Friday the average visit is 600 per day, so when calculated within 1 week in can number the visitor population by a total of 13,000 people.

\section{Sample}

The sample in this study is all visitors who come to Taman Tebing Breksi. The sampling used was Non Probability Sampling by giving a questionnaire which formed a questionnaire on each visitor who happened to visit the bridge cliff garden. The number of samples taken as many as 400 people. On the basis of sampling technique using the Slovin formula, where 400 respondents were drawn from 13,000 visitors to Taman Tebing Breksi within 1 week of research. The identification of 400 people with visitors to Taman Tebing Breksi will be very easy to find. For the use of such a technique, the formation of the extension of the 
The Effect Of Destination Management And Participation Of The Community To The Consumption Of Visitor For The Welfare Of The Tebing Breksi

Sleman Yogyakarta

state of the institution of the deficit is inaccurate. In the case of injury, it is the case that the percentage, while the latter defies the aggression of the samples depicting the population.

Activities in data analysis is to group data based on variables and types of respondents. Data analysis technique in this research using Stuctural Equation Model (SEM). Further data will be analyzed with the help of computer with the help of LISREL program. Inferential statistical analysis focuses on the field of analysis analysis and data interpretation to draw conclusions. This analysis is used to test the research hypothesis that has been determined by using the sample data obtained.

The Inferential Statistics Method used in the analysis of this research data is Structural Equation Modeling (SEM). The reason for the use of SEM in this research is that SEM has the ability to describe the relationship pattern between the latent construct variable and the manifest variable (manifest variable or indicator variable). In this study to analyze Tourism Destination Management and Public Participation on Community Welfare through Visitor Consumption at Taman Tebing Breksi Sleman, Yogyakarta.

According to Hair., Et.al (2010: 629-651) there are 5 stages in Structural Equation Modeling (SEM), namely:

a. Defines individual constructs, by selecting what items / statements are used as measurable variables (indicators).

b. Design a study to produce results empirically, by estimating the adequacy of the sample size and selecting the estimation method.

c. Estimating or assessing the validity of the measurement equation, by estimating the limit of goodnesss of fit and the construct validity of the measurement equation. If the measurement equation is not valid then the next step is to improve the measurement and design a new study. However, if the measurement equation is valid, the next step is to continue the structural equation test with stages 5 and 6 .

d. Determine the model of structural equations, by altering or combining the measurement equations to structural equations.

e. Estimating or assessing the validity of structural equations, by estimating the goodness of fit and significance, the direction and size of structural estimate estimates. If the structural equation is invalid then the next step is to fix the equation and test it with new data. If the structural equation is valid, then the next step is to illustrate the actual conclusions and recommendations.

\section{Result}

\section{Destinations Management}

The management of tourist destinations is reflected by the attractions, accessibility, facilities, and tourism organizations. The descriptive test gets average $=74.25$, in weighted form equivalent to 4,125: high category, where here interpreting that the management of the Breksi cliff tourism destination is good.

Tourism Research Journal, Volume 2 (1), 2018 
The Effect Of Destination Management And Participation Of The Community To The Consumption Of Visitor For The Welfare Of The Tebing Breksi

Sleman Yogyakarta

Table 4.14. Description of Destination Management

\begin{tabular}{|c|c|c|c|}
\hline Construct & Average & Weighted & Category \\
\hline Attraction & 17.540 & 4.385 & Very High \\
\hline Accessibility & 13.850 & 3.463 & High \\
\hline Amenity & 21.100 & 4.220 & Very High \\
\hline Anchilary & 21.755 & 4.351 & Very High \\
\hline Total & 74.245 & 4.125 & High \\
\hline
\end{tabular}

Source: Test results of primary data

From the Results Table above shows that the highest tourist attraction ( $\mathrm{x}^{-}$ $=4.385)$ is higher than the others, in this case it shows that tourist attraction is arguably the most important role in the formation or management of this breccia cliff compared to others. The next sequence that plays a role in the formation or management of this Tebing Breksi is the presence of tourism organizations, existing facilities and accessibility to Tebing Breksi.

\section{Visitor Consumption}

The visitor's consumption is reflected by the type of accommodation used, tourist income, family members, marital status, and Length of Stay. The descriptive test gets average $=54.76$, in weighted form equivalent to 3,651: high category, here interpreting that visitor consumption of Brecon Cliff also encourages economic activity in around Taman Tebing Breksi.

Table 4.15. Description of Visitor Consumption

\begin{tabular}{|c|c|c|c|}
\hline Construct & Average & Weighted & Category \\
\hline $\begin{array}{l}\text { Type of } \\
\text { Accommodation used }\end{array}$ & 11.658 & 3.886 & High \\
\hline Tourist Income & 12.958 & 4.319 & Very High \\
\hline Family members & 12.235 & 4.078 & High \\
\hline Marital Status & 6.080 & 2.027 & Low \\
\hline Long Stay & 11.838 & 3.946 & High \\
\hline Total & 54.768 & 3.651 & High \\
\hline
\end{tabular}

Source: Test results of primary data

From the results of the table above shows that the weighted categorized low is the marital status $(\bar{x}=2.027)$, it indicates less role of this marital status in terms of consumption of visitors Tebing Breksi. While the others enter the high and very high category, it indicates that Type of Accommodation, Tourist Income, Family Members from tourists and long stay of tourists in Tebing Breksi have an important role in visitor consumption in Tebing Breksi.

Tourism Research Journal, Volume 2 (1), 2018 
The Effect Of Destination Management And Participation Of The Community To The Consumption Of Visitor For The Welfare Of The Tebing Breksi

Sleman Yogyakarta

\section{Community participation}

Community participation is reflected by stakeholder engagement, and the annual meeting of the community. Descriptive test gets average $=24.86$, in the weighted form equivalent to 4,143: high categorized, here it is interpreted that the participation of the Breksi own community is well under way to assist the management of Tebing Breksi.

Table 4.16. Description of Community Participation

\begin{tabular}{|c|c|c|c|}
\hline Construct & Average & Weighted & Category \\
\hline Stakeholder engagement & 12.485 & 4.162 & High \\
\hline The annual community meeting & 12.375 & 4.125 & High \\
\hline Total & 24.860 & 4.143 & High \\
\hline
\end{tabular}

Source: Test results of primary data

Both indicators of public participation are categorized as high $(\bar{x}=4.162$ $\& \bar{x}=4.125)$. This indicates that both indicators of community participation have been able to run together well so that the participation of the Breksi Brisk community is worth a good run..

\section{Community welfare}

The welfare of the community is reflected by: Revenue, Consumption or family expenditure, Housing conditions, Residential facilities, Family member health, Ease of access to health services, Ease of getting you to education level, Ease of getting transport facilities. Descriptive test gets average $=67.568$, in weighted form equivalent to 4.49: very high category, it is interpreted that people's prosperity around Tebing Breksi is good.

Table 4.17. Description of Community Welfare

\begin{tabular}{|c|c|c|c|}
\hline Construct & Average & Weighted & Category \\
\hline Income & 8.790 & 4.510 & Very High \\
\hline Consumption or family expenditure & 8.303 & 4.300 & Very High \\
\hline State of residence & 8.035 & 4.170 & High \\
\hline Accommodation facilities & 8.753 & 4.490 & Very High \\
\hline Health of family members & 7.943 & 4.140 & High \\
\hline Ease of getting health services & 8.528 & 4.460 & Very High \\
\hline $\begin{array}{l}\text { Ease of entering you to the level of } \\
\text { education }\end{array}$ & 8.553 & 4.450 & Very High \\
\hline Easy access to transportation facilities & 8.565 & 4.450 & Very High \\
\hline Total & 67.468 & 4.490 & Very High \\
\hline
\end{tabular}

Source: Test results of primary data

Tourism Research Journal, Volume 2 (1), 2018 
The Effect Of Destination Management And Participation Of The Community To The Consumption Of Visitor For The Welfare Of The Tebing Breksi

Sleman Yogyakarta

From the results of the table above shows that the condition of the community residence around Tebing Breksi high categorized $(\bar{x}=4.170)$, as well as the health of family members of the Tebing Breksi community with a high score $(\bar{x}=4.140)$, while for others scored $>4.2$ so gets very high category. In this case interpreting that the welfare of this Tebing Breksi community can be evenly distributed on various measurement indicators (constructs).

\section{E. Discussion}

The management of a tourism destination can logically affect the consumption of visitors and the welfare of the people around the destination. can be said if the management of destinations the better the level of visitor consumption will increase and will directly improve the welfare of the community. In addition, the direct participation of citizens can also affect the consumption of visitors and the welfare of the people around the destination. Just as the management of destinations if community participation is better then the level of prosperity will also increase. From the results of existing research indicate that Tebing Breksi has been managed properly so that it can affect the level of visitor consumption, this is of course also with the participation of the community around Tebing Breksi. when a destination is well managed and a good community participation will improve the welfare of the community around Tebing Breksi.

\section{F. Conclusion}

The results of this study found significant exogenous (x) effect on endogen (y) directly or through intervening: visitor consumption. So based on the existence of these findings it is concluded:

1. The management of Tebing Breksi has been done well so that it affects the level of visitor consumption coming in Tebing Breksi, where consumption level will increase along with the running of good management.

2. Community participation Tebing Breksi directly done well, the community plays an active role in the development activities of Tebing Breksi. This also affects the level of visitor consumption, which of course will increase because with the intense community directly involved in the development activities then the tourists will also increase in consumption

3. Good Destination Management can improve the welfare of people around the destination with the consumption of visitors as a medium mediator.

4. The existence of direct community involvement is proven to improve their own welfare through visitor consumption which also increases as medium mediator. 
The Effect Of Destination Management And Participation Of The Community To The Consumption Of Visitor For The Welfare Of The Tebing Breksi

Sleman Yogyakarta

\section{REFERENCES}

Adiyoso, Wignyo. 2009. Sues Participatory Planning in Community Empowerment. Surabaya: Putra Media Nusantara

Augusty Ferdinant, 2005. Structural Equation Modeling. Semarang, Indonesia

Badrudin, Rudy, 2012. Regional Autonomy Economy, UPP STIM YKPN, Yogyakarta

Barbara G. Tabachnick, Linda S. Fidell. (2007). Using Multivariate Statistics. Boston: Pearson Education. Inc.

Boniface, Brian G. and Chris Cooper. 2005. Worldwide Destination: The Geography of Travel and Tourism (fourth edition). Oxford: Elsevier Butterworth Heinemann

Bryson, J. M., 1995, Strategic Planning for Public and Non-Organizations: Aguide to Strengthening and Sustaining Organizational Achievement, Jossey-Bass Publishers: San Francisco.

Divisekera, S. (2013 [b]), Specifications and Empirical Estimation of Tourism Demand Models: A Review, Chapter 3 in Handbook of Tourism Economics, Clem Tisdell (ed), The World Scientific Publishing Company

Divisekera, S with Nguyen, V (2014), Regional Variations in Tourist Consumption Patterns: A Model of Demand for Domestic Tourism in Australia. College of Business Victoria UniversityMelbourne, Australia

Ernie Tisnawati Sule, Kurniawan Saefullah. 2009. Introduction to Management. Jakarta: Kencana.

Ghozali, Imam. 2005. Application of Multivariate Analysis with SPSS. Semarang: UNDIP Publishing Agency.

Goldman G, Nakazawa A, Taylor D (2008) Impact of Visitor Expenditures on Local Revenues. Alaska: WRDC

Gunn, Clare A with Turgut Var. (2002). Tourism Planning Basic, Concepts, Cases. New York: Routledge.

H. Oka A. Yoeti. 2002. Strategic Planning of Regional Marketing Tourism Destination. Publisher PT. Pradnya Paramita, Jakarta.

Hair et al. (2010). Multivariate Data Analysis, Seventh Edition. Pearson Prentice Hall

Joseph F.Hair JR., William C. Balack, Barry J.Babin, Rolph E.Anderson, (2010). Multivariate Data Analysis 7 / e. Pearson Prentice Hall, USA.

Likert, Rensis (1932), "A Technique for the Measurement of Attitudes", Archives of Psychology 140: 1-55

ISTA Assessment Matrix 2017

Middleton, Victor T. C. (2001). Marketing in Travel and Tourism 3rd Edition. MPG Books Ltd, Bodmin.

Nawawi A, 2013, Community Participation In The Management Of Depok Beach Tourism In Kretek Parangtritis Village, National Journal of Tourism Volume 5, Number 2, August 2013 (103 - 109) ISSN: 1411-9862

Tourism Research Journal, Volume 2 (1), 2018 
The Effect Of Destination Management And Participation Of The Community To The Consumption Of Visitor For The Welfare Of The Tebing Breksi

Sleman Yogyakarta

Nicolau JL, Más FJ (2005) Heckit modeling of tourist expenditure: evidence from Spain. International Journal of Service Industry Management 16 (3)

Paul D, Lumsdon L, Weston R (2009) Visitor expenditure: the case of cycle re creation and tourism. Journal of Sport \& Tourism 14 (1)

Pendit, Nyoman S. 2003. Tourism Science An Introduction to Prime. Jakarta: Pradnya Paramita

Richardson, John I and Martin Fluker. 2004. Understanding and ManagingTourism. Australia: Person Education Australia, NSW Australia.

Saptutynigsih, Endah. 2003. Impact of Holiday Spending on Household Income in Indonesia Structural Path Analysis (Spa) Approach In Snse Indonesia. Journal of Economic Development Faculty of Economics, University of Muhammadiyah Yogyakarta Vol. 8 No. 1, June 2003.

Siregar. I. 2001, Thesis Penanggulanagn poverty through the empowerment of fishing communities, University of Indonesia, Depok.

Slamet, M. 2003. Establishing the Human Behavior Pattern of Development. IPB Press. Bogor

Spicker, Paul, 1988. Principles Of Social Welfare. First published 1988 by Routledge, ISBN 0-415-00630-9 and 0-415-00631-7

Sugiharto, Eko, 2007. Community Welfare Level of Fishermen of Desa Benua Baru Ilir Based on Central Statistics Agency Indicators

Sugiyono, 2007, Business Research Methodology, PT. Gramedia, Jakarta

Sztompka, Piotr. 2007. Sociology of social change. Jakarta: Prenada

Todaro, Michael P and Smith, Stephen C 2006. Economic Development, Jakarta: Erland

Uma Sekaran, 1992, Research Methodology for Business, Issue 4, Book 1, Jakarta: Salemba Four

Law of the Republic of Indonesia, No. 11 Year 2009 on People's Welfare

Yamin, Sofyan \& Heri Kurniawan, 2009. SPSS Complete, Jakarta: Salemba Four.

Zastrow, Charles. 2000. Introduction to Social Work and Social Welfare. United States: Brooks Cole.

Tourism Research Journal, Volume 2 (1), 2018 